\title{
EFFECTS OF DEFICIENCY AND EXCESS OF PHOSPHORUS AND POTASSIUM IN HYDROPONICS ON SELECTED PHYSIOLOGICAL AND BIOMETRICAL TRAITS OF BASKET WILLOW (Salix viminalis L.)
}

\section{WPŁYW NIEDOBORU I NADMIARU FOSFORU ORAZ POTASU W HYDROPONIKACH NA WYBRANE CECHY FIZJOLOGICZNE I BIOMETRYCZNE WIERZBY WICIOWEJ (Salix viminalis L.)}

Department of Plant Physiology and Biochemistry, West Pomeranian University of Technology, Szczecin, Poland

\begin{abstract}
Streszczenie. Wierzba wiciowa (Salix viminalis L.) jest gatunkiem należącym do tzw. roślin energetycznych, wykorzystywanych jako odnawialne źródło energii. W przeprowadzonych badaniach poddano ocenie wpływ niedoboru i nadmiaru fosforu oraz potasu na wybrane cechy fizjologiczne dwóch genotypów wierzby wiciowej klonów 'Bjor' oraz 'Tora', uprawianych metodą hydroponiczną. Celem badań był wybór genotypu bardziej odpornego na zakłócone stosunki troficzne w środowisku. Do pożywki pełnej Hoaglanda (kontrola) dodawano 20 i $40 \%$ fosforu lub potasu oraz zmniejszano w niej zawartość tych pierwiastków także o 20 i 40\%. Określono liczbę pędów wytworzonych przez rośliny, długość i dynamikę wzrostu pędów, plon świeżej i suchej masy części nadziemnej oraz systemu korzeniowego, a także bilans wodny obu badanych klonów wierzby wiciowej. Otrzymane wyniki wskazują, iż klon 'Tora' i 'Bjor' charakteryzują się podobną odpornością na zmienne warunki żywienia fosforem oraz potasem.
\end{abstract}

Key words: basket willow, phosphorus fertilization, potassium fertilization, biomass yield.

Słowa kluczowe: wierzba wiciowa, nawożenie fosforem, nawożenie potasem, plon biomasy.

\section{INTRODUCTION}

Renewable energy technology is an extremely important issue in the era of civilization progress when energy demand is always growing. According to Directive 2009/28 /EC drawn up by the European Union on April 23, 2009, by 2020 20\% of electricity should come from RES (Renewable Energy Sources), such as biomass. One of the so-called energy crops (19 MJ per 1kg) (Szczukowski et al. 2004), used for energy production is willow (Salix L.) (Borjesson 1996; Niemczyk et al. 2016), especially basket willow (Salix viminalis L.) (Jeżowski et al. 2011; Rosén et al. 2011). I In 2010 the plant was cultivated in Poland in the area of 10-12 thousand hectares (Nowak et al. 2012). Willow is used for the purpose of protecting and shaping the environment and also in phytoremediation processes (Mleczek et al. 2009; Złoch et al. 2015). It is characterized not only by the high biomass yield but it also

Corresponding author - Adres do korespondencji: Małgorzata Mikiciuk, Department of Plant Physiology and Biochemistry, West Pomeranian University of Technology, Szczecin, Juliusza Słowackiego 17, 71-434 Szczecin, Poland, e-mail: malgorzata.mikiciuk@zut.edu.pl 
easily adapts to new environmental conditions. It has relatively high resistance to pollutants present in the soil (Jama-Rodzeńska et al. 2016) and is capable of selective accumulation of pollutants (Meers et al. 2007; Mleczek et al. 2010; Malinowska et al. 2015). Under Polish climatic conditions, the willow can produce even a dozen tonnes of dry matter per hectare of the plantation (Dubas et al 2004). For energy purposes, properly processed wood of willow in the form of chips, briquettes or pellets are used as primary fuel (direct combustion) or as secondary fuel (wood gas) (Szczukowski et al. 2004; Jakubowski 2005).

In degraded areas, where willow is used for rehabilitation purposes very often, due to anthropogenic activity, the natural trophic relationships in the soil are disrupted, resulting in negative effects on plant growth and development.

The purpose of the study was to determine the effect of deficiency and excess of phosphorus and potassium on selected physiological traits of willow clones and selection genotype with higher resistance. Phosphorus and potassium are macroelements that have many important physiological functions. Both deficiency and excess of these elements causing growth and water management disturbances and of plants.

\section{MATERIAL AND METHODS}

In the study two clones of basket willow (Salix viminalis L.): 'Bjor' and 'Tora' from the plantation of Department of Plant Physiology and Biochemistry of the West Pomeranian University of Technology in Szczecin was used. Hydroponic flowerpot experiments were conducted in the vegetation hall of the Faculty of Environmental Management and Agriculture $\left(53^{\circ} 25^{\prime} \mathrm{N}, 14^{\circ} 32^{\prime} \mathrm{E}, 25 \mathrm{~m}\right)$, under shelter, by complete randomization method in the two-way system, in triplicate - one sample was one flowerpot.

First experimental factor was varied composition of media. Following variants were used: Control (full-strenght Hoagland nutrient medium), $+20 \% \mathrm{P},+20 \% \mathrm{~K},+40 \% \mathrm{P},+40 \% \mathrm{~K}$, $-20 \%$ P,$-20 \%$ K, $-40 \%$ P, $-40 \%$ K. Second experimental factor was willow genotype: 'Bjor' and 'Tora'. The composition of Hoagland full-strength nutrient medium was modified so as not to alter the content of other nutrients during increasing or decreasing the phosphorus or potassium content.

On April 27, cutting of willows (20 centimeters of one-year shoots) of both willow clones were placed ( 3 pcs per flowerpot) into Kick and Grosse-Braukman containers (with a capacity of $\left.10 \mathrm{dm}^{3}\right)$. The containers was filled with a mixture of perlite and rinsed gravel $(1: 1)$ and $3.5 \mathrm{dm}^{3}$ of full-strength Hoagland medium.

After one month, when the plants had developed roots and several twelve-centimeter shoots, the media were differentiated in terms of phosphorus or potassium content according to experimental variants. During the experiment, the volume of the medium in the flowerpots was systematically supplemented.

The tested clones were evaluated for the following physiological traits: average number of shoots produced by a single plant, average length of shoots, fresh and dry mass of the aboveground part and root system in nine repetitions and water balance of plants.

The water balance was determined twice during vegetation, in the third decade of June (I term) and July (II term), in the full season of willow vegetation growing in different conditions of 
feeding with phosphorus and potassium, by relative water content in leaf tissues (RWC) and leaf tissue water saturation deficit (WDS). Other characteristics (number and length of shoots and yield of fresh and dry ground and root crop) were determined in the first decade of September, after completion of the experiment, based on measurements of all plants.

Essential data were obtained after weighing on an analytical balance of six randomly selected leaf from each combination. Fresh leaf mass was determined immediately after harvest, the weight of full saturation with water after 24 hours of soaked in water and dried with tissue paper and dry mass after drying the leaves to constant weight at $105^{\circ} \mathrm{C}$ in a drying oven.

Results of the study were statistically analyzed using a two-way analysis of variation in complete randomization. The significance of differences between means was determined using Duncan's test, with significance level $\alpha=0.05$.

\section{RESULTS AND DISCUSSION}

An average number of shoots produced by the basket willow in Sulima's research (2006) 2.2 shoot per plant in the first year of cultivation and according to Styszko et al. (2008) from 1 to 10 shoot per plant after about two years of plant growth. Compared willow clones did not differ in the number of shoots produced. It has been shown that clons developed the smallest number of shoots under control conditions and in the variant $+20 \% \mathrm{~K}$. By analyzing the interaction of experimental factors, it can be concluded that in all combinations the plants produced 3 shoots - only Tora's clone under control and feeding $+20 \% \mathrm{~K}$ developed 2 shoots (Table 1).

Table 1. Number and length of shoots of 'Tora' and 'Bjor' basket willow clones growing under conditions of deficiency and excess of phosphorus and potassium

Tabela 1. Liczba oraz długość pędów klonów 'Tora' i 'Bjor' wierzby wiciowej rosnącej w warunkach niedoboru i nadmiaru fosforu oraz potasu

\begin{tabular}{|c|c|c|c|c|c|c|}
\hline \multirow{2}{*}{$\begin{array}{c}\text { Level of phosphorus }(\mathrm{P}) \\
\text { or potassium }(\mathrm{K}) \\
\text { Poziom żywienia fosforem }(\mathrm{P}) \\
\text { lub potasem }(\mathrm{K})\end{array}$} & \multicolumn{3}{|c|}{$\begin{array}{l}\text { No. of shoots [shoot/plant] } \\
\text { Liczba pędów [szt./roślina] }\end{array}$} & \multicolumn{3}{|c|}{$\begin{array}{c}\text { Shoot lenght } \\
\text { Długość pędów [cm] }\end{array}$} \\
\hline & ‘Bjor' & 'Tora' & Avg. & 'Bjor' & 'Tora' & Avg. \\
\hline$-20 \% \mathrm{P}$ & $3.0^{\mathrm{b}}$ & $3.0^{\mathrm{b}}$ & $3.0^{\mathrm{b}}$ & $117.2^{\mathrm{abc}}$ & $118.3^{\mathrm{abc}}$ & $117.7^{a}$ \\
\hline$+20 \% \mathrm{P}$ & $3.0^{\mathrm{b}}$ & $3.0^{\mathrm{b}}$ & $3.0^{\mathrm{b}}$ & $146.5^{\mathrm{c}}$ & $78.2^{\mathrm{a}}$ & $112.3^{a}$ \\
\hline$-40 \% \mathrm{P}$ & $3.0^{\mathrm{b}}$ & $3.0^{\mathrm{b}}$ & $3.0^{\mathrm{b}}$ & $147.7^{\mathrm{c}}$ & $122.2^{\mathrm{abc}}$ & $134.9^{a}$ \\
\hline$+40 \% \mathrm{P}$ & $3.0^{\mathrm{b}}$ & $3.0^{\mathrm{b}}$ & $3.0^{\mathrm{b}}$ & $96.4^{a, b}$ & $129.5^{\mathrm{bc}}$ & $112.9^{a}$ \\
\hline$-20 \% \mathrm{~K}$ & $3.0^{\mathrm{b}}$ & $3.0^{\mathrm{b}}$ & $3.0^{\mathrm{b}}$ & $138.7^{\mathrm{bc}}$ & $130.5^{\mathrm{bc}}$ & $134.6^{\mathrm{a}}$ \\
\hline$+20 \% \mathrm{~K}$ & $3.0^{\mathrm{b}}$ & $2.0^{\mathrm{a}}$ & $2.5^{a}$ & $114.8^{\mathrm{abc}}$ & $146.0^{c}$ & $130.4^{\mathrm{a}}$ \\
\hline$-40 \% \mathrm{~K}$ & $3.0^{\mathrm{b}}$ & $3.0^{\mathrm{b}}$ & $3.0^{\mathrm{b}}$ & $120.3^{\mathrm{abc}}$ & $132.5^{\mathrm{bc}}$ & $126.4^{a}$ \\
\hline$+40 \% \mathrm{~K}$ & $3.0^{\mathrm{b}}$ & $3.0^{\mathrm{b}}$ & $3.0^{\mathrm{b}}$ & $142.7^{\mathrm{bc}}$ & $118.8^{\mathrm{abc}}$ & $130.7^{\mathrm{a}}$ \\
\hline $\begin{array}{l}\text { Control } \\
\text { Kontrola }\end{array}$ & $3.0^{\mathrm{b}}$ & $2.0^{\mathrm{a}}$ & $2.5^{a}$ & $143.5^{c}$ & $136.8^{\mathrm{bc}}$ & $140.1^{a}$ \\
\hline $\begin{array}{l}\text { Average for clones } \\
\text { Średnia dla klonów }\end{array}$ & $3.0^{\mathrm{a}}$ & $2.8^{\mathrm{a}}$ & - & $128.4^{\mathrm{a}}$ & $123.6^{a}$ & - \\
\hline
\end{tabular}

Averages marked with the same letters do not differ significantly with significance level $\alpha=0.05-$ Średnie oznaczone tymi samymi literami nie różnią się istotnie przy poziomie istotności $\alpha=0,05$.

Sulima (2006) states, that the height of the basket willow in the first year of vegetation is $2.04 \mathrm{~m}$. In studies by Mant et al. (2003) after 19 weeks of growth under control conditions reached more than $2.5 \mathrm{~m}$ tall, with a weekly increase of approximately $11.55 \mathrm{~cm}$. According 
to Styszko et al. (2008) after about two years of plant growth reached a height of from $239.4 \mathrm{~cm}$ to $315.8 \mathrm{~cm}$. In our research, the clones Bjor and Tora after approx. 16 weeks of vegetation achieved similar but slightly lower than quoted in the literature height, with an average of 128.4 and $123.6 \mathrm{~cm}$, respectively.

Statistical analysis showed that the varied composition of media, as well as the genotype of the plant, did not significantly affect the length of willow shoots. However, the significance of the interaction of experimental factors was demonstrated. Least shoot length, significantly less than the shoot length of Bjor control and in the variants of $-40 \% \mathrm{P}$ and $+20 \% \mathrm{~K}$, was the Tora clone in the variant $+20 \% \mathrm{P}$ (Table 1 ).

Borkowska's et al. (2015) studies showed that phosphorus fertilization of pensylvanian mallow did not affect the length of shoots, which is consistent with the results of own research.

In the case of the yield of fresh mass of the aboveground part of plants, the significance of main effects of the experience has been demonstrated. The highest average yield of fresh mass was obtained from the variant $-20 \% \mathrm{P}$ (102.25 g per plant) and $+40 \% \mathrm{~K}(96.75 \mathrm{~g}$ per plant). According to Mleczek et al. (2010) the production of willow biomass is dependent on taxon (from $0.14 \mathrm{~kg}$ fresh mass per shrub in S. viminalis '1047a' to $6.81 \mathrm{~kg}$ fresh mass per shrub per year for $S$. alba var. Chermesina). The authors also showed that the dry matter to fresh mass ratio was 0.46 on average.

In Borkowska et al. (2015) research it has been shown that phosphorus used at 39 and $52 \mathrm{~kg} \cdot \mathrm{ha}^{-1}$ (each spring for 8 years) was significantly affected by increase in biomass yields. In our studies, the willow genotype also differentiated the yield of fresh weight - greater than 'Tora' (81.6 g per plant) was obtained by 'Bjor' (92.9g per plant). Influence of the interaction of experimental factors on the discussed feature was varied. It was shown that 'Bjor' was characterized by a higher fresh mass of aboveground part than 'Tora' in the variants of $-40 \% \mathrm{P},-20 \% \mathrm{~K},+20 \% \mathrm{~K}$ and control conditions (Fig. 1). In studies conducted by Stolarski et al. (2002) and Nowak and Jasiewicz (2012) yield of fresh annual shoots of Salix viminalis L. were $37.10 \mathrm{t} \cdot \mathrm{ha}^{-1}$ and from 25.8 to $29.2 \mathrm{t} \cdot \mathrm{ha}^{-1}$ respectively.

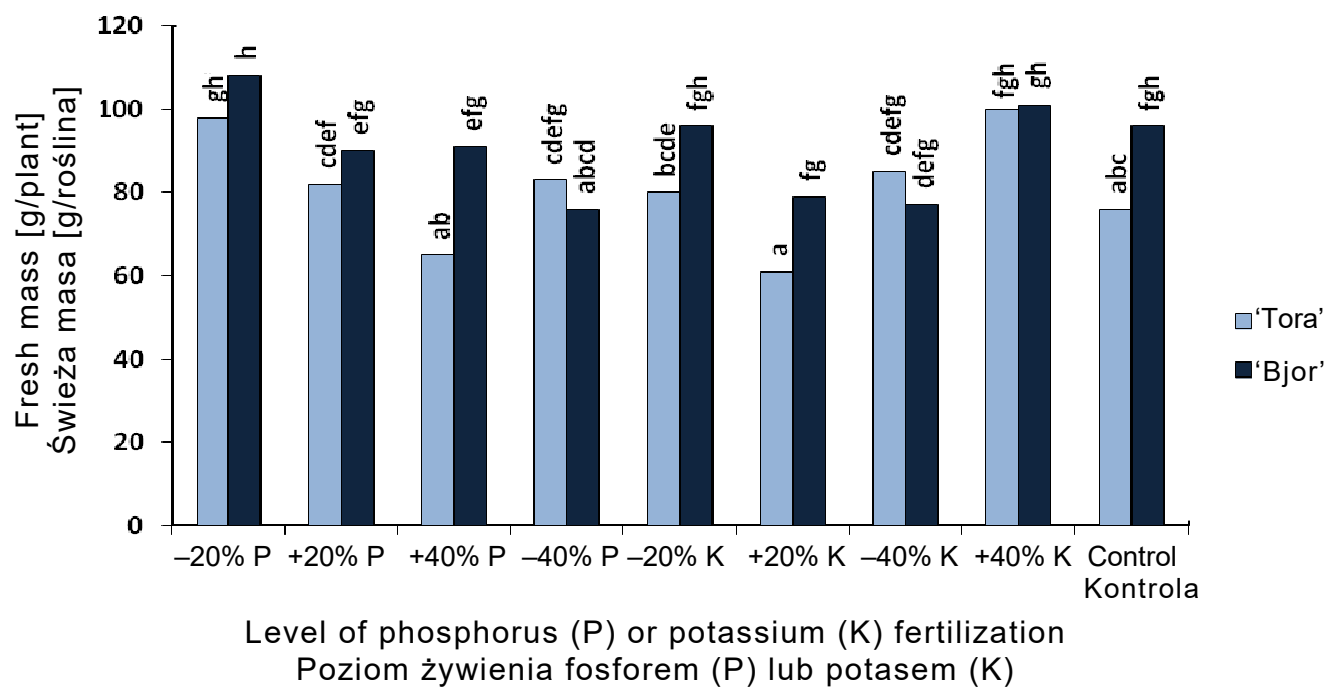

Fig. 1. Fresh mass of aboveground part 'Tora' and 'Bjor' basket willow clones growing under conditions of deficiency and excess of phosphorus and potassium. Averages marked with the same letters do not differ significantly with significance level $\alpha=0.05$

Ryc. 1. Świeża masa części nadziemnej klonów ‘Tora' i ‘Bjor’ wierzby wiciowej rosnącej w warunkach niedoboru i nadmiaru fosforu oraz potasu. Średnie oznaczone tymi samymi literami nie różnią się istotnie przy poziomie istotności $\alpha=0,05$ 
Statistical analysis did not show that average fresh weight of root system of compared clones differed significantly. However, It has been proven, that composition of the medium was affected this trait. The highest yield of the fresh root system (for both clones) was obtained in the variant of $-20 \% \mathrm{~K}(107.9 \mathrm{~g}$ per plant) and the lowest in $+40 \% \mathrm{P}(68.6 \mathrm{~g}$ per plant). By analyzing the interaction of experimental factors, there was shown that 'Bjor' developed higher fresh weight of root system under conditions of increased and reduced dietary (by $20 \%$ ) both of phosphorus and potassium, than 'Tora'. The same relationship was also found in 'Bjor' at $-40 \% \mathrm{P}$ (Fig. 2).

In Heinsoo et al. (2009) research on the production of root biomass of Salix viminalis and Salix dasyclados showed that average value of root biomass ranged from 1.8 to $3.8 \mathrm{t} \cdot \mathrm{ha}^{-1}$. This study has shown that the application of nitrogen-phosphorus-potassium fertilization has reduced production of root biomass of willow.

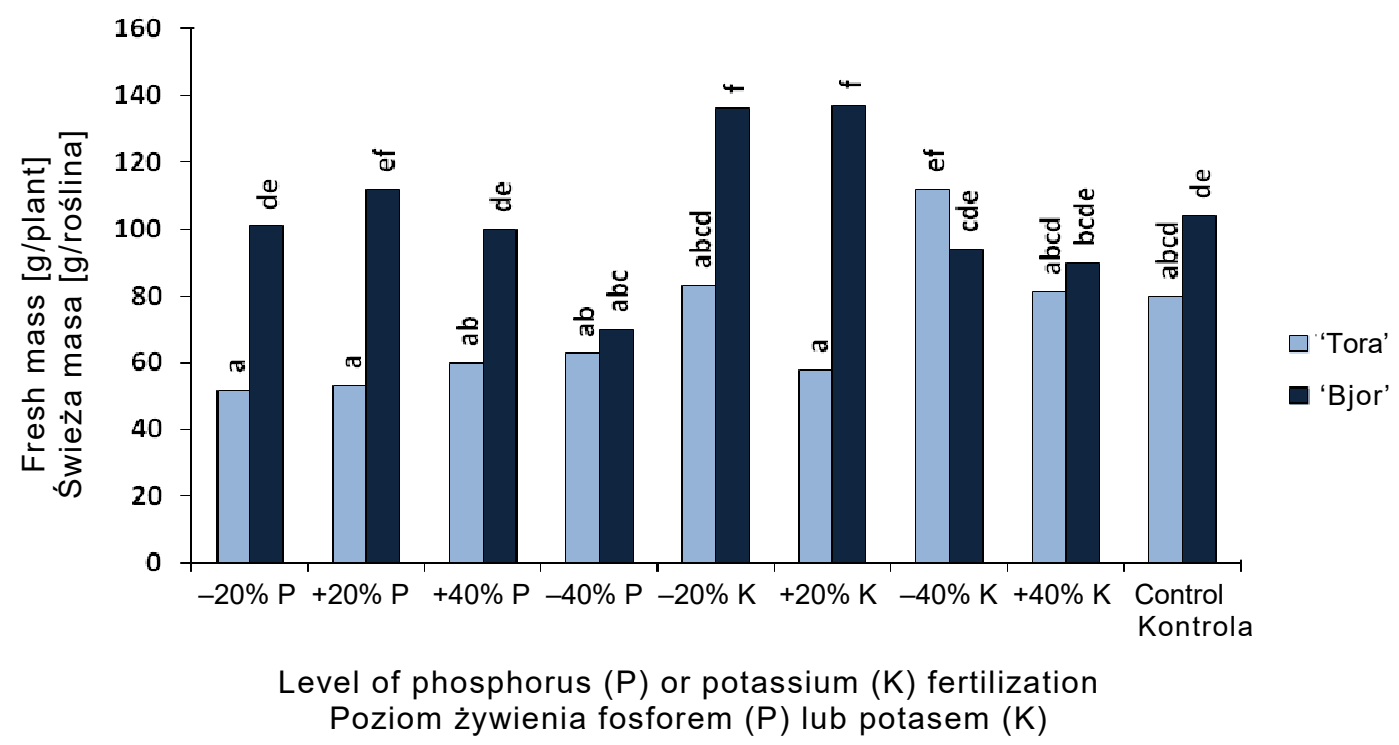

Fig. 2. Fresh weight of root system of 'Tora' and 'Bjor' basket willow clones growing under conditions of deficiency and excess of phosphorus and potassium. Averages marked with the same letters do not differ significantly with significance level $\alpha=0.05$

Ryc. 2. Świeża masa systemu korzeniowego klonów 'Tora' i ‘Bjor' wierzby wiciowej rosnącej w warunkach niedoboru i nadmiaru fosforu oraz potasu. Średnie oznaczone tymi samymi literami nie różnią się istotnie przy poziomie istotności $\alpha=0,05$

Compared willow genotypes did not differ in terms of yield of dry matter of aboveground part. However, the differential composition of the media had a significant effect on this feature. The highest dry mass of the aboveground part was obtained in the variant of $-20 \% \mathrm{P}$ (27.8 $\mathrm{g}$ per plant). By analyzing the interaction of experimental factors, it can be concluded that under the conditions of excess (of $40 \%$ ) of both phosphorus and potassium in media, the greater yield of dry matter obtained by 'Tora'. For 'Bjor' it was shown that diversity of plant nutrition with both phosphorus and potassium (except for the $-20 \% \mathrm{P}$ variant) resulted in a decrease in the dry matter mass of the plant above control sample (Fig. 3).

In Heinsoo et al. (2009) research showed that NPK fertilization resulted in increased dry matter of foliage (leaf and wood) compared to control (non-fertilized plants) in Salix viminalis 
and Salix dasyclados. In Faber et al. (2007) research, the yield of willow wood (Salix viminalis) was dependent on the type of soil and length of harvest cycle (greater yields were obtained over a 3-year cycle than in the annual harvest). Similar results were obtained by Kuś and Matyka (2010), whose dry weight of willow wood in annual harvest ranged from 12.7 to $14.4 \mathrm{t} \cdot \mathrm{ha}^{-1}$, whereas in the 3-year harvest cycle, depending on the type of soil, by 21 to $28 \%$.

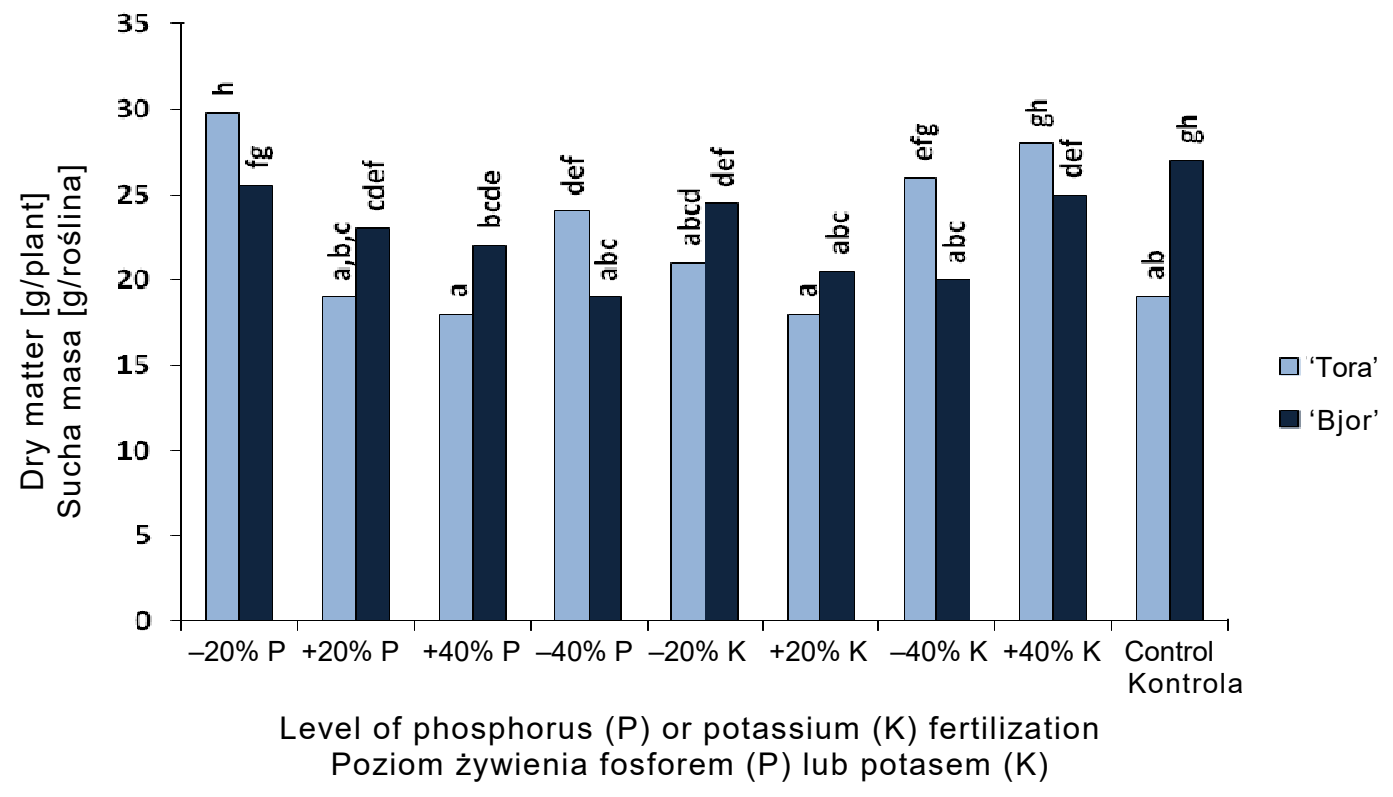

Fig. 3. Dry matter of aboveground part of 'Tora' and 'Bjor' basket willow clones growing under conditions of deficiency and excess of phosphorus and potassium. Averages marked with the same letters do not differ significantly with significance level $\alpha=0.05$

Ryc. 3. Sucha masa części nadziemnej klonów 'Tora' i 'Bjor' wierzby wiciowej rosnącej w warunkach niedoboru i nadmiaru fosforu oraz potasu. Średnie oznaczone tymi samymi literami nie różnią się istotnie przy poziomie istotności $\alpha=0,05$

No significant influence of the main experience factors on the crop yield of the willow root system was shown. However, the significance of the interaction of these factors was found. In all experimental variants, apart from the variant $+20 \% \mathrm{~K}$, the compared willow clones possessed a root system of similar dry mass. In the variant $+20 \% \mathrm{~K}$, 'Bjor' was characterized by a larger dry root mass than other variants (Fig. 4).

In Borkowska et al. (2009) research on Virginia mallow showed that increase of phosphorus dose (from $39.28 \mathrm{~kg} \cdot \mathrm{ha}^{-1}$ to $52.38 \mathrm{~kg} \cdot \mathrm{ha}^{-1}$ of the pure constituent and in both cases combined with $100 \mathrm{~kg} \cdot \mathrm{ha}^{-1}$ nitrogen also of pure constituent) resulted in a slight increase in the dry matter of root mass of this species. In Heinsoo et al. (2009) research, it was found that applied NPK fertilization caused the decreased of the dry matter content of Salix viminalis and Salix dasyclados as compared to control.

Indicators of relative water content in leaves (RWC) and tissue water saturation deficit (WSD) are one of the most important parameters commonly used for assessing plant water management. Plants characterized by low RWC usually shows low photosynthetic activity (Tezara et al. 2002). 


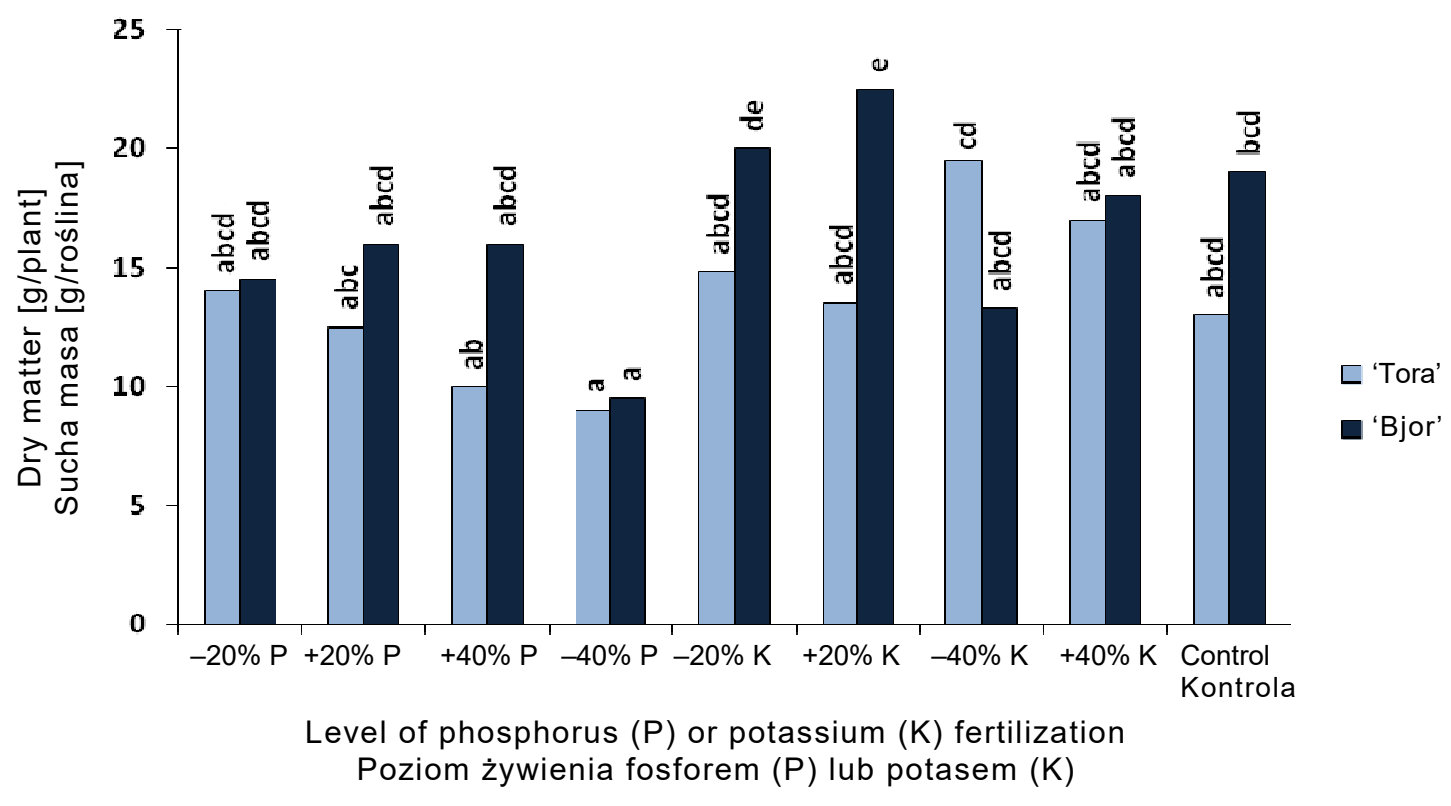

Fig. 4. Dry matter of root system of 'Tora' and 'Bjor' basket willow clones growing under conditions of deficiency and excess of phosphorus and potassium. Averages marked with the same letters do not differ significantly with significance level $\alpha=0.05$

Ryc. 4. Sucha masa systemu korzeniowego klonów 'Tora' i 'Bjor' wierzby wiciowej rosnącej w warunkach niedoboru i nadmiaru fosforu oraz potasu. Średnie oznaczone tymi samymi literami nie różnią się istotnie przy poziomie istotności $\alpha=0,05$

Water balance indices (RWCs, WSDs) vary according to the factors of experience and the timing of the assay.

In 'Tora' the highest value of the relative water content index in leaf (RWC) was recorded in the II term, in variant $+20 \% \mathrm{~K}$, and the lowest in the variant $+40 \%$ in the same period. In 'Bjor' the highest value of this indicator was recorded In the second term, in $40 \%$ of potassium deficiency, while the lowest was in the variant $+40 \% \mathrm{P}$ (Table 2 ).

Table 2. Water balance indicators (RWC, WSD) [\%] of 'Tora' and 'Bjor' basket willow clones growing under conditions of deficiency and excess of phosphorus and potassium

Tabela 2. Wskaźniki bilansu wodnego (RWC, WSD) [\%] klonów 'Tora' i 'Bjor' wierzby wiciowej rosnącej w warunkach niedoboru i nadmiaru fosforu oraz potasu

\begin{tabular}{|c|c|c|c|c|c|c|c|c|}
\hline \multirow{3}{*}{$\begin{array}{c}\text { Level of phosphorus }(\mathrm{P}) \\
\text { or potassium }(\mathrm{K}) \\
\text { Poziom żywienia } \\
\text { fosforem }(\mathrm{P}) \text { lub } \\
\text { potasem }(\mathrm{K})\end{array}$} & \multicolumn{4}{|c|}{$\begin{array}{l}\text { I term } \\
\text { I termin }\end{array}$} & \multicolumn{4}{|c|}{$\begin{array}{c}\text { II term } \\
\text { II termin }\end{array}$} \\
\hline & \multicolumn{2}{|c|}{ 'Bjor' } & \multicolumn{2}{|c|}{ 'Tora' } & \multicolumn{2}{|c|}{ 'Bjor' } & \multicolumn{2}{|c|}{ 'Tora' } \\
\hline & RWC & WSD & RWC & WSD & RWC & WSD & RWC & WSD \\
\hline$-20 \% \mathrm{P}$ & 79.20 & 20.80 & 87.50 & 12.50 & 88.95 & 11.05 & 84.70 & 15.30 \\
\hline$+20 \% \mathrm{P}$ & 79.85 & 20.15 & 80.65 & 19.35 & 87.35 & 12.65 & 94.10 & 5.90 \\
\hline$-40 \% \mathrm{P}$ & 80.40 & 19.60 & 82.05 & 17.95 & 94.30 & 5.70 & 84.10 & 15.90 \\
\hline$+40 \% \mathrm{P}$ & 75.20 & 24.80 & 81.30 & 18.70 & 78.30 & 21.70 & 80.15 & 19.85 \\
\hline$-20 \% \mathrm{~K}$ & 79.25 & 20.75 & 83.55 & 16.45 & 82.50 & 17.50 & 81.30 & 18.70 \\
\hline$+20 \% \mathrm{~K}$ & 83.60 & 16.40 & 91.00 & 9.00 & 84.80 & 15.20 & 94.85 & 5.15 \\
\hline$-40 \% \mathrm{~K}$ & 82.40 & 17.60 & 88.40 & 11.60 & 96.35 & 3.65 & 91.40 & 8.60 \\
\hline$+40 \% \mathrm{~K}$ & 80.50 & 19.50 & 81.90 & 18.10 & 84.20 & 15.80 & 93.10 & 6.90 \\
\hline $\begin{array}{l}\text { Control } \\
\text { Kontrola }\end{array}$ & 77.10 & 22.90 & 82.30 & 17.70 & 82.65 & 17.35 & 89.75 & 10.25 \\
\hline
\end{tabular}


In both terms of indication, in 'Tora' was found markedly increase of the indicator in medium supplemented with $20 \% \mathrm{~K}$ (respectively $8.70 \%$ and $5.10 \%$ relative to control). At the second term, in 'Tora' the addition of phosphorus to the medium at $20 \%$ reduced WSD. Further increase in the phosphorus content $(+40 \%)$ resulted in opposite effect (an increase in WSD index).

In clone 'Bjor' for the second time indication in plants grown in medium with $40 \%$ deficiency of phosphorus, an increase in values of the relative water content of $8.65 \%$ compared to plants grown under control conditions was found (Table 2).

\section{RECAPITULATION}

Based on conducted studies, willow genotypes which was subjected to biometric comparisons (number and length of shoots) well tolerate differentiated phosphorus and potassium content in the medium. 'Bjor' showed a higher yield of fresh mass of aboveground part. It was also shown that under conditions of a $40 \%$ reduction in phosphorus content, it was distinguished by a higher fresh mass, not only shoots but also root system. 'Bjor' clone was also characterized by a larger dry mass of root system under conditions of increased $20 \%$ potassium nutrition. Under conditions of differentiated feeding with phosphorus and potassium, the highest yield of fresh mass of aboveground part was obtained by plants from the variant of $-20 \% \mathrm{P}$. The reduction of relative water content in the leaves of the studied willow genotypes was noted in the case of enrichment of $40 \%$ phosphorus media.

\section{REFERENCES}

Borjesson P.I. 1996. Energy analysis of biomass production and transportation. Biom. Bioener. 11, 305-318.

Borkowska H., Molas R., Kupczyk A. 2009. Virginia fanpetals (Sida hermaphrodita Rusby) cultivated on light soil; Height of yield and biomass productivity. Pol. J. Environ. Stud. 18, 563-568.

Borkowska H., Molas R., Skiba D. 2015. Plonowanie ślazowca pensylwańskiego w wieloletnim użytkowaniu [Virginia fanpetals yielding in multi-year use]. Acta Agrophys. 22(1), 5-15. [in Polish]

Dubas J.W., Grzybek A., Kotowski W., Tomczyk A. 2004. Wierzba energetyczna - uprawa i technologie przetwarzania. Bytom, Wyż. Szk. Ekon. Administr., 35. [in Polish]

Faber A., Stasiak M., Kuś J. 2007. Wstępna ocena produkcyjności wybranych gatunków roślin energetycznych [Preliminary evaluation of productivity of the selected energy crops]. Progr. Plant Protect. / Post. Ochr. Rośl. 47(4), 339-346. [in Polish]

Heinsoo K., Merilo E., Petrovits M., Koppel A. 2009. Fine root biomass and production in a Salix viminalis and Salix dasyclados plantation. Estonian J. Ecol. 58(1), 27-37.

Jakubowski T. 2005. Określenie ilości przyjętych sztobrów wierzby wiciowej (Salix viminalis var. Gigantea) w uprawie naturalnej. Infrastruktura i ekologia terenów wiejskich. Kraków, Wydaw. PAN, 35-45. [in Polish]

Jama-Rodzeńska A., Bocianowski J., Nowak W., Ciszek D., Nowosad K. 2016. The influence of communal sewage sludge on the content ofmacroelements in the stem of selected clones of willow (Salix viminalis L.). Ecol. Eng. 87, 212-217.

Jeżowski S., Głowacka K., Kaczmarek Z., Szczukowski S. 2011. Yield traits of eight common osier clones in the first three years following planting in Poland. Biom. Bioen. 35, 1205-1210.

Kuś J., Matyka M. 2010. Plonowanie i cechy biometryczne wierzby w zależności od warunków siedliskowych [Yielding and biometric characters of energy willow depending on the habitat conditions]. Probl. Inż. Rol. 3, 59-65. [in Polish] 
Malinowska K., Malinowski R., Stera A. 2015. Physiological re action of common osier (Salix viminalis L.) var. Jorr to the presence of lead in the subsoil. J. Ecol. Eng. 16(2), 110-115.

Mant C., Peterkin J., May E., Butler J. 2003. A feasibility study of a Salix viminalis gravel hydroponic system to renovate primary settled wastewater. Biores. Technol. 90, 19-25.

Meers E., Vandecasteele B., Ruttens A., Vangronsveld J., Tack F.M.G. 2007. Potential of five willow species (Salix spp.) for phytoextraction of heavy metals. Environ. Exp. Bot. 60, 57-68.

Mleczek M., Łukaszewski M., Kaczmarek Z., Rissmann I., Golinski P. 2009. Efficiency of selected heavy metals accumulation by Salix viminalis roots. Environ. Exp. Bot. 65, 48-53.

Mleczek M., Rutkowski P., Rissmann I., Kaczmarek Z., Golinski P., Szentner K., Strazynska K., Stachowiak A. 2010. Biomass productivity and phytoremediation potential of Salix alba and Salix viminalis. Biom. Bioener. 34, 1410-1418.

Niemczyk M., Wojda T., Kontorowicz W. 2016. Przydatność hodowlana wybranych odmian topoli w plantacjach energetycznych o krótkim cyklu produkcji [Silvicultural potential of selected poplar cultivars growing on short rotation plantations]. Sylwan 160(4), 292-298. [in Polish]

Nowak D., Jasiewicz C. 2012. Wpływ nawożenia mineralnego i kompostu na plon i skład chemiczny wierzby energetycznej [Influence of mineral fertilizer and compost on yield and chemical composition with willow]. Agric. Eng. 4(139), 295-301. [in Polish]

Rosén K., Fricks Y. von, Vinichuk M., Sennerby-Forsse L. 2011. Accumulation of ${ }^{137} \mathrm{Cs}$ after potassium fertilization in plant organs of Salix viminalis L. and in combusted ash. Biom. Bioener. 35, 2765-2772.

Stolarski M., Szczukowski S., Tworkowski J. 2002. Produktywność klonów wierzb krzewiastych uprawianych na gruntach ornych w zależności od częstotliwości zbioru i gęstości sadzenia [Productivity of willow short rotation coppice in one-year cutting cycles]. Fragm. Agronom. 2, 39-51. [in Polish]

Styszko L., Fijałkowska D., Sztyma M. 2008. Obserwacje rozwoju wierzby energetycznej w 2007 roku [Developmental observations of energetic willow in 2007]. Rocz. Ochr. Środ. 10, 425-432. [in Polish]

Sulima P., Przyborowski J.A., Stolarski M. 2006. Ocena przydatności wybranych gatunków wierzby do celów energetycznych [Evaluation of biomass of selected perennial plants utilized for energy purposes]. Fragm. Agronom. 3, 290-297. [in Polish]

Szczukowski S., Tworkowski J., Stolarski M. 2004. Wierzba energetyczna. Kraków, Wydaw. Plantpress Sp. z o.o., 6-9. [in Polish]

Tezara W., Mitchall V., Driscoll S.P., Lawlor D.W. 2002. Effects of water deficit and its interaction with $\mathrm{CO}_{2}$ supply on the biochemistry and physiology of photosynthesis in sunflower. J. Exp. Bot. 375, 1781-1791.

Złoch M., Tyburski J., Hrynkiewicz K. 2015. Analysis of microbiologically stimulated biomass of Salix viminalis $\mathrm{L}$. in the presence of $\mathrm{Cd}^{2+}$ under in vitro conditions - implications for phytoremediation. Acta Biol. Cracov., Ser. Botanica 57(2), 67-78.

\footnotetext{
Abstract. Basket willow (Salix viminalis L.) is one of so-called energy crops, which are used to renewable energy source. In conducted research rated effects of deficiency and excess of phosphorus and potassium on selected physiological traits of two willow genotypes: 'Bjor' and 'Tora' in hydroponics. The purpose of the study was to select genotype which is more resistant to disturbed trophic relationships in the environment. To full Hoagland medium (control sample) added $20 \%$ and $40 \%$ phosphorus and potassium and also reduced the content of these elements by $20 \%$ and $40 \%$. A number of shoots produced by plants, the length the shoots, yield of the fresh and dry mass of the aboveground and root systems and water balance of both examined willows were determined. The results indicated that the 'Tora' and 'Bjor' are similarly resistant to variable nutritional conditions by phosphorus and potassium.
} 
